\title{
Correct names for some of the closest relatives of Carica papaya: A review of the Mexican/ Guatemalan genera Jarilla and Horovitzia
}

\author{
Fernanda Antunes Carvalho', Susanne S. Renner ${ }^{2}$ \\ I Systematic Botany and Mycology, Ludwig-Maximilians-Universität München, Menzinger Strasse 67, \\ D-80638 Munich, Germany \\ Corresponding author: Fernanda Antunes Carvalho (antunesfc@gmail.com)
}

Academic editor: K. Marhold | Received 14 August 2013 | Accepted 7 November 2013 | Published 19 November 2013

Citation: Carvalho FA, Renner SS (2013) Correct names for some of the closest relatives of Carica papaya: A review of the Mexican/Guatemalan genera Jarilla and Horovitzia. PhytoKeys 29: 63-74. doi: 10.3897/phytokeys.29.6103

\begin{abstract}
Using molecular data, we recently showed that Carica papaya L. is sister to a Mexican/Guatemalan clade of two genera, Jarilla Rusby with three species and Horovitzia V.M. Badillo with one. These species are herbs or thin-stemmed trees and may be of interest for future genomics-enabled papaya breeding. Here we clarify the correct names of J. heterophylla (Cerv. ex La Llave) Rusby and J. caudata (Brandegee) Standl., which were confused in a recent systematic treatment of Jarilla (McVaugh 2001). We designate epitypes for both, provide weblinks to type specimens, a key to the species of Jarilla and Horovitzia, and notes on their habitats and distribution.
\end{abstract}

\section{Keywords}

Caricaceae, nomenclature, epitypification, papaya sister clade

\section{Introduction}

The family Caricaceae Dumort. comprises 34 species and one formally named hybrid in currently six genera. A molecular phylogeny that included all species revealed that Carica papaya L. (the only species in the genus Carica) is sister to a clade of four species endemic to Mexico and Guatemala (Carvalho and Renner 2012). The discovery that the closest relatives of C. papaya are three herbs in the genus Jarilla Rusby and 
a thin stemmed tree, Horovitzia cnidoscoloides (Lorence \& R. Torres) V. M. Badillo, has implications for plant breeders, who have so far tried in vain to cross papaya with tree species in the genus Vasconcellea A. St.-Hil., known as the highlands papayas. To facilitate communication among researchers from different fields, and since full-genome sequencing of the species of Jarilla and Horovitzia is ongoing (R. Ming, UrbanaChampaign, personal communication, Aug. 2013), we here provide a conspectus of the four species that are the closest relatives of papaya and clean up a nomenclatural confusion involving two names in the genus Jarilla.

We start with the nomenclatural issues, then provide a key to the four species, and end with brief comments on the range and habitat of each species.

\section{Nomenclature of Jarilla}

Pablo de La Llave (1832), a director of the National Museum of Natural History of Mexico, was the first to describe one of the unusual herbaceous Caricaceae that are today placed in Jarilla. He had access to fruiting specimens only and based his description of the flowers on notes made by Vicent Cervantes, a professor of botany in Mexico City and one of the founders of that city's botanical garden in 1788. La Lave gave his new species the epithet "heterophilla" [sic] to refer to its variably shaped leaves. To mark the distinctness of the new species, he placed it in a separate genus, Mocinna, honoring the Mexican naturalist José Mariano Mociño. Unfortunately, this overlooked that Lagasca in 1816 had already described an Asteraceae genus by that name. Soon thereafter, George Bentham (1839) described the same species as Carica nana, based on an unnumbered Hartweg specimen (Fig. 1) collected in 1836 in Léon (Guanajuato, Mexico). The holotype at K (Fig. 1) bears the number 288 on its label, a number corresponding to the page of Plantae Hartwegianae on which C. nana was described. Diaz-Luna and Lomeli-Sención (1992), in their revision of Jarilla, cite this collection as Hartweg $255(\mathrm{~K})$, probably due to a misreading of 288 for 255.

The second herbaceous Caricaceae species was named in March 1894 by Townshend S. Brandegee, who described Carica caudata from the Cape region of Baja California, Mexico, based on a plant he collected the year before (Fig. 2). In August of the same year, José Ramírez, unaware of Brandegee's publication, described a new variety of the first herbaceous Caricaceae, $M$. heterophylla La Llave, naming it varietas sesseana, based on living plants from Guanajuato and Jalisco. Unfortunately, he appears to have made no herbarium specimens, but only two beautiful plates showing the typical variety and var. sesseana (Fig. 3). Comparison of the plate of var. sesseana and the holotype of $C$. caudata leaves no doubt that these names refer to the same species, and we therefore agree with previous assessments (Diaz-Luna and Lomeli-Sención 1992, Badillo 1993) that they are synonyms.

Realizing that Mocinna La Llave was a younger homonym of Mocinna Lag., Henry Hurd Rusby (1921) proposed the substitute name Jarilla, derived from the Spanish vernacular name Jarrila, for $M$. heterophylla. He also up-ranked var. sesseana as a separate species, Jarilla sesseana (Ramírez) Rusby. We agree with Diaz-Luna and Lomeli-Sención 
(1992) and McVaugh (2001) that Rusby's publication of the substitute name Jarilla meets the requirement for valid publication and that Ivan M. Johnston's (1924) slightly later publication of the name Jarrilla (the correct Spanish spelling) to replace Mocinna is a superfluous name. At around the same time, Standley (1924) realized that Carica caudata Brandegee belonged in Jarilla and was in fact an older name for J. heterophylla var. sesseana Ramírez (= Jarilla sesseana (Ramírez) Rusby), and he accordingly changed the name to J. caudata. He also described a third herbaceous species of Caricaceae, Jarilla chocola Standley, based on two collections made in 1935 from Sonora, Mexico (Standley 1937).

Thus, by 1937 it was clear there were three species of Jarilla and also what their correct names were. In their revision of the genus, Diaz-Luna and Lomeli-Sención (1992) designated plate II of Ramírez (1894; our Fig. 3 left-hand plate) as the lectotype of J. heterophylla var. sesseana and plate $\mathrm{V}$ as the neotype of var. heterophylla (our Fig. 3 right-hand plate). Unfortunately, the most recent study of Jarilla, that of Rogers McVaugh (2001), synonymized the two taxa distinguished by Ramírez. This error is surprising given the different leaves and fruits of Ramírez's two varieties (our Fig. 3), and indeed McVaugh seems to have been aware he might be making a mistake because he writes (2001: 469), "In the following I have drawn heavily upon the work of Diaz-Luna and Lomelí-Sención, whose personal observations of these interesting species greatly increased our knowledge of them, and have indeed provided almost all the available information about the living plants. Errors introduced here, as a result of faulty translation or interpretation of the work of these authors, or otherwise, are solely my responsibility."

We agree with Diaz-Luna and Lomeli-Sención (1992) and the earlier workers cited above that Jarilla heterophylla var. heterophylla is the oldest name for Bentham's Carica nana, while var. sesseana is a younger synonym of Carica caudata. We have accordingly up-dated the names of our previous Jarilla heterophylla and J. nana sequences in GenBank (Carvalho and Renner 2012; all of which are vouchered). Together, the descriptions of Ramírez (1894), Brandegee (1894), Rusby (1921), Johnson (1924), Standley (1924), and Diaz-Luna and Lomeli-Sención (1992) provide a clear idea of the morphological distinctions of the two species: Jarilla caudata has rounded to ovate or deltoid (never hastate) leaves, c. $1 \mathrm{~cm}$ (rarely longer) male flowers, and $10 \mathrm{~cm}$ long fruits that are narrowed at the base with five horn-like appendages, each 3-6 cm long (Fig. 4). Jarilla heterophylla has hastate leaves, $0.5 \mathrm{~cm}$ long male flowers, and c. $3 \mathrm{~cm}$ long fruits with short and thick appendages as shown in Fig. 5.

To fix the usage of the two names more reliably, we below designate epitypes to serve as interpretative specimens for plates II and V of Ramírez (1894), following Art. 9.8 of the Melbourne Code (McNeill et al. 2012). The plates published by Ramírez fail to include staminate and pistillate flowers for both species and therefore do not precisely fix the application of the names of these dioecious species. In addition, physical specimens also can help in evolutionary studies because they can yield DNA that may be used in future comparisons. We chose as epitypes complete male and female specimens from the same population. The epitypes are deposited in M. Isoepitypes of Mocinna heterophylla Cerv. ex La Llave var. sesseana (=Jarilla caudata (Brandegee) 


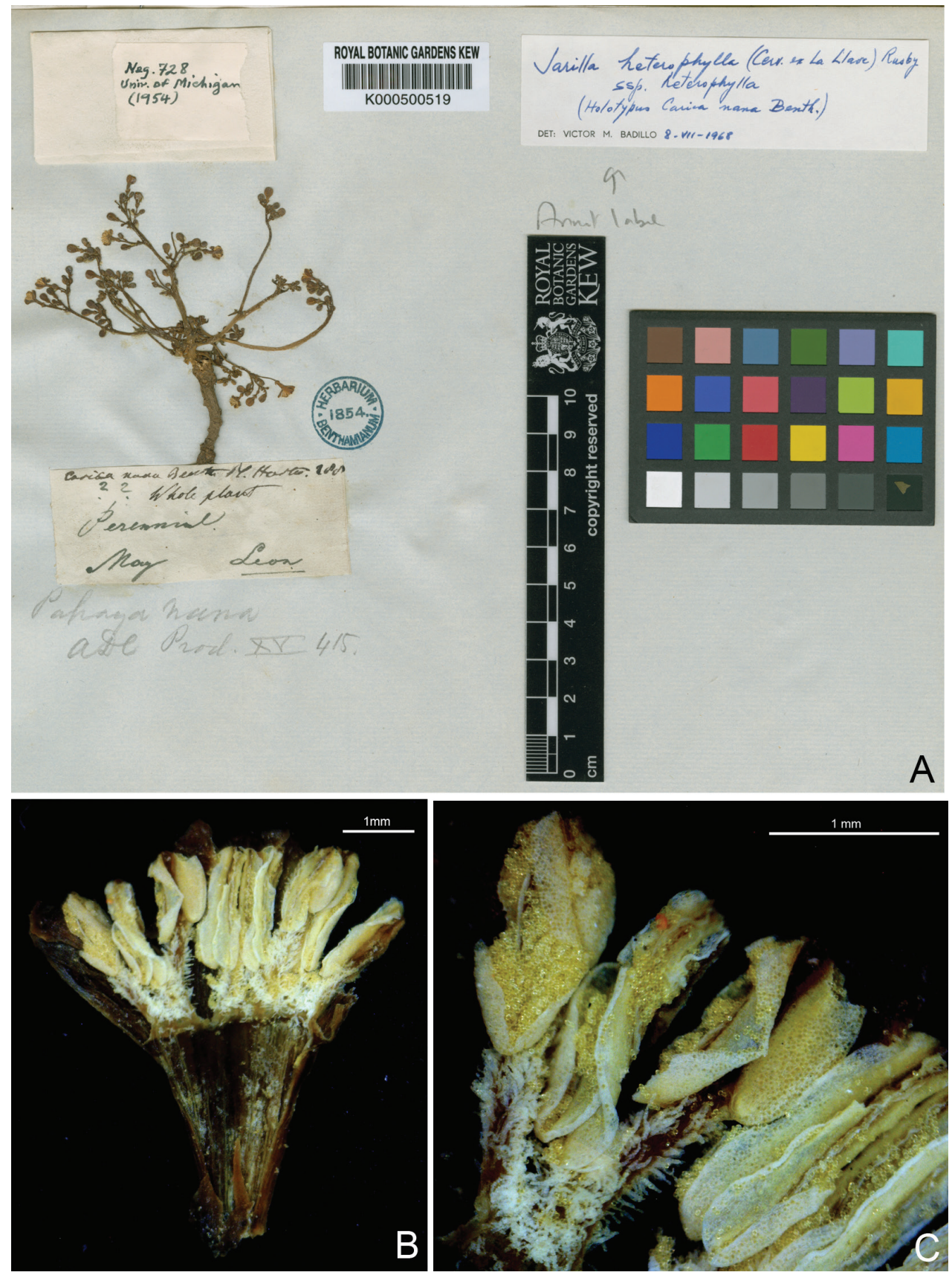

Figure I.Holotype of Carica nana Benth. A Specimen in K(http://www.kew.org/herbcatimg/202388.jpg) B Photo of an opened flower showing the arrangement of the anthers and the pistillode (arrow) C Closeup of the anthers. Filaments are densely covered by moniliform trichomes. $\mathbf{B}$ and $\mathbf{C}$ were taken by the first author in $\mathrm{K}$. 


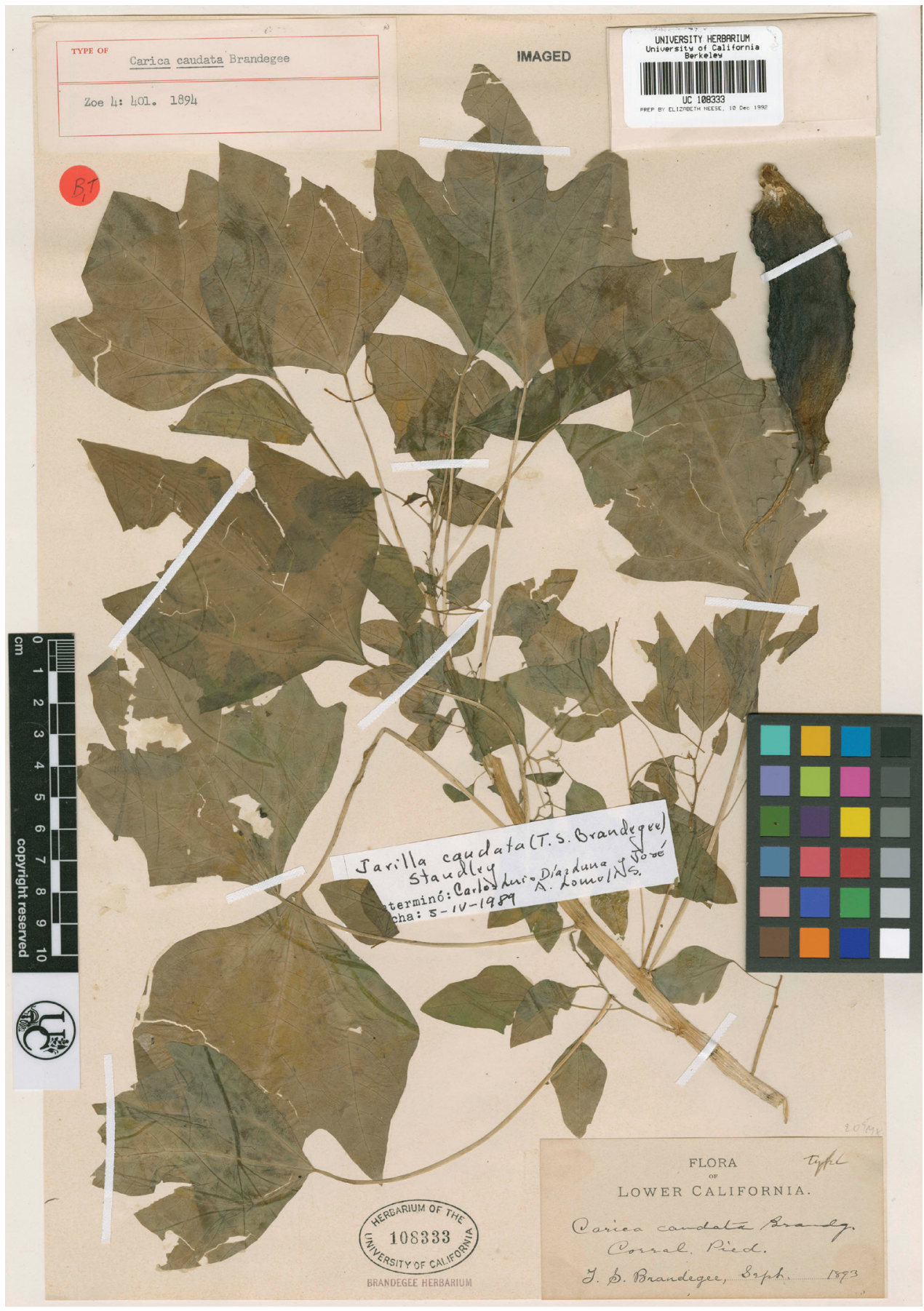

Figure 2. Holotype of Carica caudata Brandegee (http://ucjeps.berkeley.edu/new_images/UC108333.jpg) 


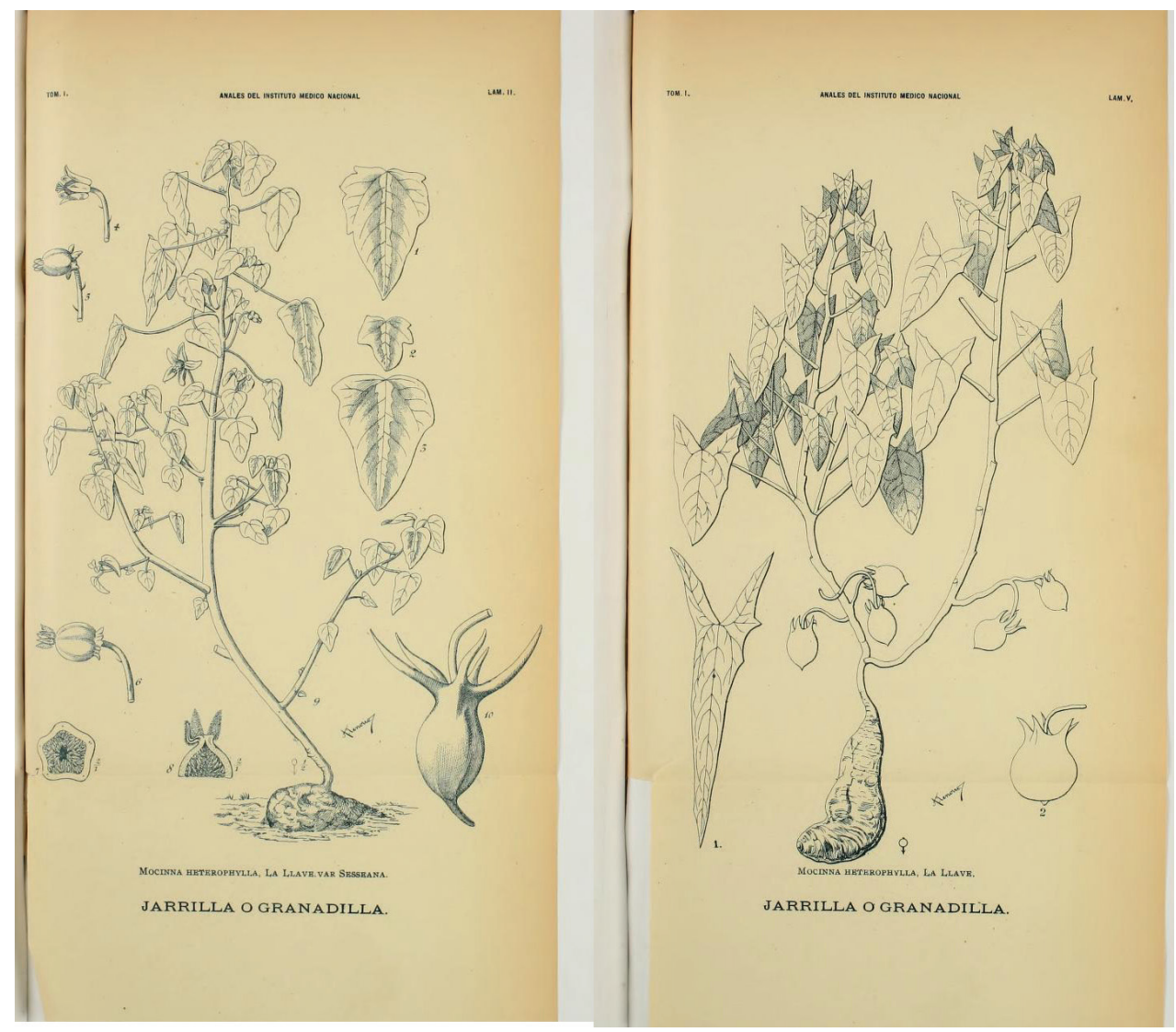

Figure 3. The two varieties of Mocinna heterophylla La Llave. Left plate shows the lectotype of Mocinna heterophylla var. sesseana Ramírez. Right plate shows the neotype of Mocinna heterophylla var. heterophylla, both designated by Díaz and Lomeli-Sención (1992). Plates reproduced from Ramírez (1894).

Standl.) are in MEXU and NY. Isoepitypes of Mocinna heterophylla Cerv. ex La Llave (= Jarilla heterophylla (Cerv. ex La Llave) Rusby) are in MEXU, NY and K.

The four species in the Jarillal Horovitzia clade can be distinguished from all other Caricaceae and from each other, using a combination of the plastid markers trnLtrnF and psbA-trnH (Carvalho and Renner 2012; GenBank accessions JX091966, JX091977, JX091975, JX091978, JX092054, JX092064, JX092065, JX092066).

\section{Key to the species of Jarilla and Horovitzia}

1a Small tree, completely covered by stinging hairs...Horovitzia cnidoscoloides

1b Herb, glabrous or pubescent, but never with stinging hairs 
2a Erect herb. Leaves lobate, rarely entire. Ovary and mature fruits with 5 longitudinal wings. Female flowers 7-9 $\mathrm{mm}$ long. Male flowers 5-9 $\mathrm{mm}$ long .....

Jarilla chocola

2b Procumbent herb, sometimes using understory plants for support. Leaves entire, rarely lobed. Ovary and young fruits with 5 basal appendages, but not winged. Female flowers 5-15 mm long. Male flowers 4-12 mm long... 3

3a Mature fruits 6-30 cm long with 5 horn-like basal appendages $3-6 \mathrm{~cm}$ long. Seeds black, 4-5.5 mm long. Male flowers in general $>1 \mathrm{~cm}(1-1.7 \mathrm{~cm})$

Jarilla caudata

3b Mature fruits $2-4 \mathrm{~cm}$ long with 5 curved basal appendages $0.5-2 \mathrm{~cm}$ long. Seeds light brown, $2.5-3.5 \mathrm{~mm}$ long. Male flowers in general $<1 \mathrm{~cm}(0.3-0.8 \mathrm{~cm}) \ldots .$.

Jarila heterophylla

Epitypification and comments on morphology and habitats

Horovitzia cnidoscoloides (Lorence \& R. Torres) V.M. Badillo, Rev. Fac. Agron. (Maracay) 43: 104. 1993.

http://species-id.net/wiki/Horovitzia_cnidoscoloides

Carica cnidoscoloides Lorence \& R. Torres, Syst. Bot. 13(1): 107-109, f.1. 1988.

Type: Mexico. Oaxaca: Ixtlan, Sierra de Juárez, 9 March 1986, $R$. Torres \& P. Teonorio 8168 (holotype: MEXU, a photo in GUADA; isotypes: BM, MO [MO-193213], NY[00112155]). Mexico. Oaxaca. Type locality, 25 May 1883, T. Cedillo \& Lorence 2347 (paratype: MEXU, a photo in GUADA, a duplicate in MO); 4 Ago 1985, Lorence et al. 4733 (paratype: MEXU, a duplicate in BM); 9 Mar 1985, C. Torres \& L. Tenorio 8167 (paratype: MEXU); 27 Ago 1986, C. Torres \& L. Tenorio 8760 (paratype: MEXU).

Horovitzia cnidoscoloides is a small tree, $0.5-4 \mathrm{~m}$ tall endemic to Sierra de Juarez in Oaxaca, Mexico. It occurs in cloud forests from 800 to $1600 \mathrm{~m}$ above sea level. Unusual features are subcapitate stigma, and stinging hairs covering the entire plant.

Jarilla chocola Standl. Publ. Field Mus. Nat. Hist., Bot. Ser. 17: 200.1937. http://species-id.net/wiki/Jarilla_chocola

Type. Mexico. Sonora: Chihuahua, Guasarema, Rio Mayo, 10 August 1936, H. S. Gentry 2366 (holotype: F; isotypes: GUADA photo, K [K000500520], S [S-G-3434]). Mexico. Sonora: San Bernardo, Rio Mayo, 14 August 1935, H. S. Gentry 1624 (paratype: F, duplicates in MEXU and K [000500521], a photo in GUADA). 


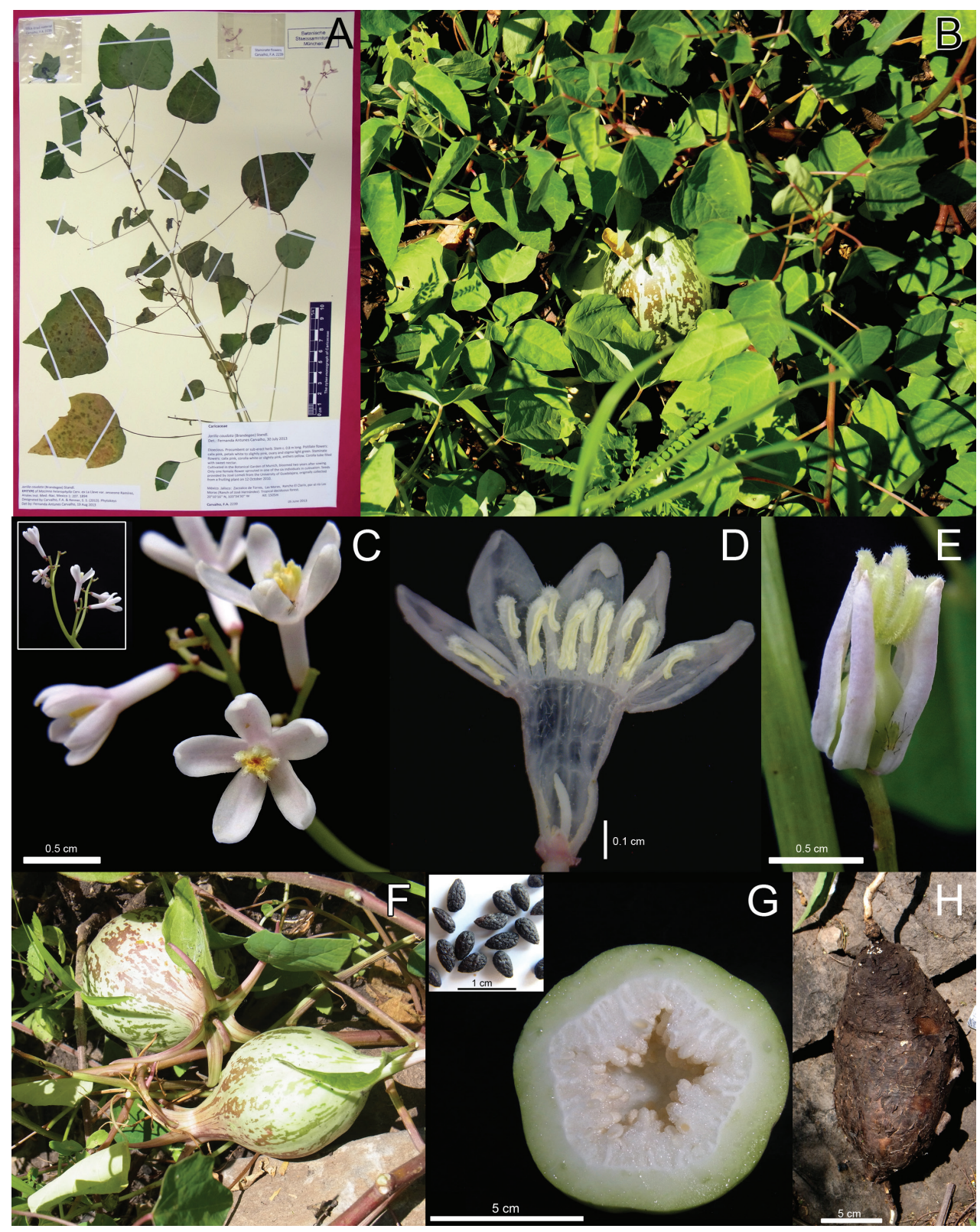

Figure 4. Jarilla caudata (Brandegee) Standl. A Epitype of Mocinna heterophylla La Llave (F.A. Carvalho 2240, M) B Habit C Male inflorescence D Staminate flower. E Pistillate flower F Fruits G Ovary unilocular and seeds $\mathbf{H}$ Tuber. 
Jarilla chocola is an erect herb, with mostly lobate leaves and fruits with 5 longitudinal wings. The species occurs at low altitudes $(100-1300 \mathrm{~m})$ along the Pacific Coast from Sonora to El Salvador.

Jarilla caudata (Brandegee) Standl., Contr. U.S. Natl. Herb. 23(4): 853. 1924. http://species-id.net/wiki/Jarilla_caudata

Fig. 4

Carica caudata Brandegee, Zoe 4: 401. 1894.

Type: Mexico. Baja California Sur: Corral de Piedra, September 1893, Brandegee s.n. (holotype: UC[UC108333]).

Mocinna heterophylla var. sesseana Ramírez, Anales Inst. Med.-Nac. Mexico 1: 207. 1894.

Type: Plate II of Ramírez, 1894 (lectotype designated by Diaz-Luna and Lomeli-

Sención 1992: 81). Mexico, Jalisco, Zacoalco de Torres, Las Moras, 5 June 2013, F.

A. Carvalho 2239 (epitype, designated here: M; isoepitypes: MEXU, NY).

Jarilla sesseana (Ramírez) Rusby, Torreya 21: 47. 1921.

Remarks. Jarilla caudata is morphologically and phylogenetically closely related to $J$. heterophylla. Their main distinguishing features are the fruits, which in J. caudata can attain a length of $30 \mathrm{~cm}$, having a smooth surface and 5 long, horn-like appendages (3-6 $\mathrm{cm}$ long). Other differences are given in the key. The species occurs in deciduous forests and fields of Baja California and central Mexico from 1500 to $1800 \mathrm{~m}$ above sea level.

Jarilla heterophylla (Cerv. ex La Llave) Rusby, Torreya 21(3): 50. 1921. http://species-id.net/wiki/Jarilla_heterophylla

Fig. 5

Mocinna heterophylla Cerv. ex La Llave, Reg. Trim. 1(3): 351. 1832.

Type: Plate V of Ramírez, 1894 (neotype, designated by Diaz-Luna and LomeliSención 1992: 88). Mexico, Jalisco, Zacoalco de Torres, Las Moras, 5 June 2013, F. A. Carvalho 2240 (epitype, designated here: M; isoepitypes: MEXU, NY, K).

Carica nana Benth., Pl. Hartw. 288. 1849.

Type: Mexico. Guanajuato, Leon, K. T. Hartweg s.n. (holotype K [K000500519]; isotype: G-DC n.v.).

Papaya nana (Benth.) A. DC., Prodr. 15(1): 415. 1864.

Jarilla nana (Benth.) McVaugh, Fl. Novo-Galiciana 3: 475. 2001.

Remarks. For differences from Jarilla caudata see under that species and in the key. Jarilla heterophylla occurs in oak forests, deciduous forests, and abandoned fields of central Mexico at 1500 to $2700 \mathrm{~m}$ above sea level. 


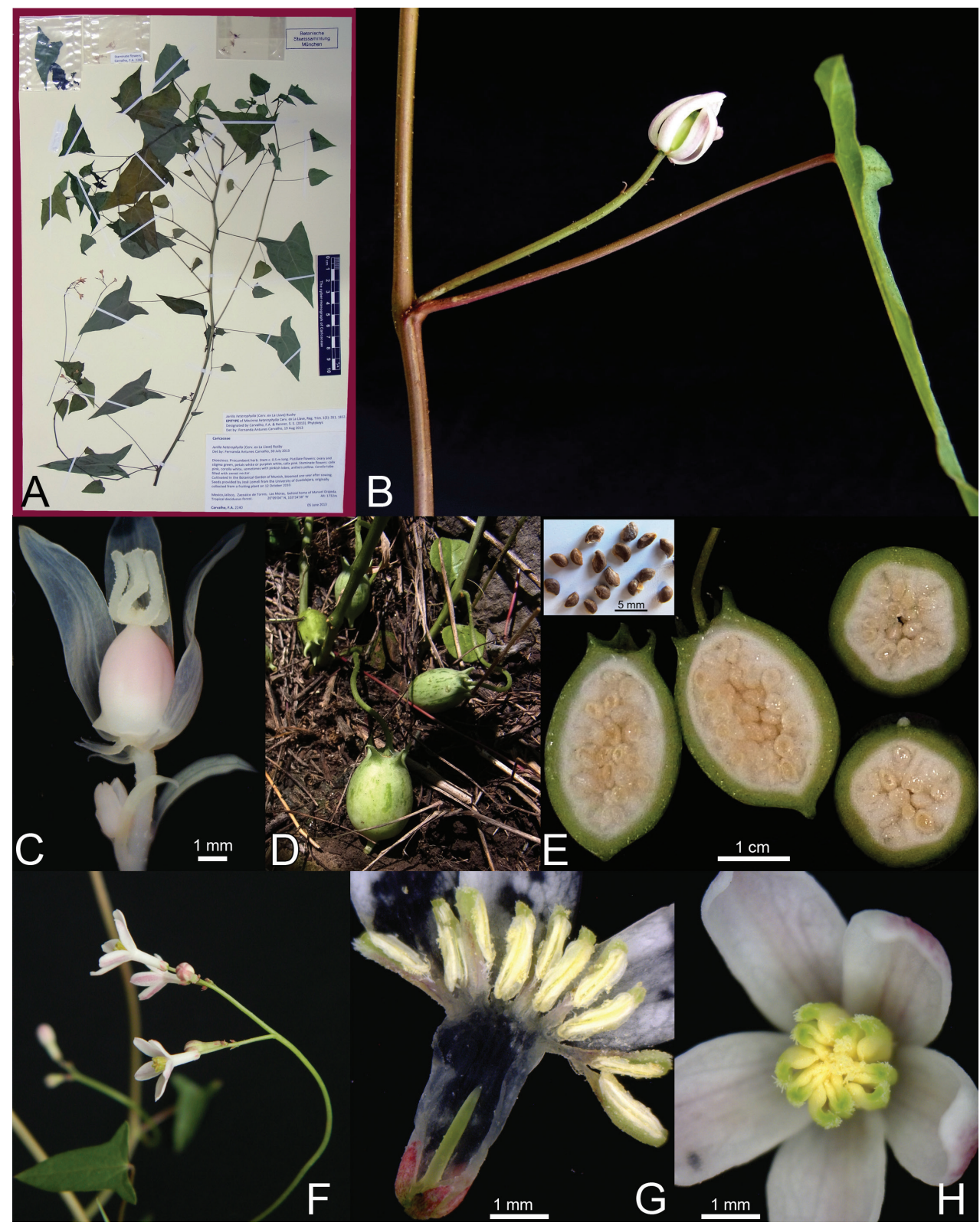

Figure 5. Jarilla heterophylla (Cerv. ex La Llave) Rusby. A Epitype of Mocinna heterophylla La Llave var. sesseana Ramírez (F.A. Carvalho 2239, M) B Female inflorescence (uniflora). C Female flower showing the short appendages at the base of the ovary D-E Fruits and seeds $\mathbf{F}$ male inflorescence $\mathbf{G}-\mathbf{H}$ Staminate flowers. 


\section{Weblinks to type specimens}

Carica caudata Brandegee, holotype:

http://ucjeps.berkeley.edu/new_images/UC108333.jpg [accessed 30.07.2013]

Carica cnidoscoloides Lorence \& R. Torres, isotypes:

http://www.tropicos.org/Image/11116 [accessed 11.08.2013]

http://sweetgum.nybg.org/vh/specimen.php?irn=707429 [accessed 11.08.2013]

Carica nana Benth., holotype: http://www.kew.org/herbcatimg/202388.jpg [accessed 30.07.2013]

Jarilla chocola Standl., isotypes:

http://apps.kew.org/herbcat/getImage.do?imageBarcode=K000500520 [accessed 11.08.2013]

http://andor.nrm.se/kryptos/fbo/kryptobase/large/S-G-003001/S-G-3434.jpg [accessed 11.08.2013]

Mocinna heterophylla Cerv. ex La Llave, epitype:

http://herbaria.plants.ox.ac.uk/bol/caricaceae [accessed 11.10.2013]

Mocinna heterophylla var. sesseana Ramírez, epitype:

http://herbaria.plants.ox.ac.uk/bol/caricaceae [accessed 11.10.2013]

\section{Acknowledgements}

We thank J. F. Barêa Pastore for discussion of the nomenclature of Jarilla, and the herbaria K, MO, NY, S, and UC for providing open access to type images. The first author is supported by a fellowship from Conselho Nacional de Desenvolvimento Científico e Tecnológico (CNPq 290009/2009-0), and additional funding came from the German Research Foundation (DFG RE 603/13).

\section{References}

Badillo VM (1993) Caricaceae, segundo esquema. Revista de la Faculdad de Agronomia de la Universidad Central de Venezuela 43: 1-111.

Bentham G (1839) Plantae Hartwegianae. London, Facsimile edition: Lehre J. Cramer 1970. http://www.biodiversitylibrary.org/page/796739\#page/288/mode/1up [accessed 30.07.2013]

Brandegee TS (1894) Additions to the flora of the Cape region of Baja California. II. Zoe 4(4): 398-407. http://www.biodiversitylibrary.org/page/568039\#page/97/mode/1up [accessed 30.07.2013]

Carvalho FA, Renner SS (2012) A dated phylogeny of the papaya family (Caricaceae) reveals the crop's closest relatives and the family's biogeographic history. Molecular Phylogenetics and Evolution 65(1): 46-53. doi: 10.1016/j.ympev.2012.05.019 
Diaz-Luna CL, Lomelí-Sención JA (1992) Revisión del género Jarilla Rusby (Caricaceae). Acta Botánica Mexicana 20: 77-99. http://www.redalyc.org/pdf/574/57402010.pdf [accessed 30.07.2013]

Johnston IM (1924) Taxonomic notes concerning the American Spermatophytes. New or otherwise noteworthy plants. Contributions from the Gray Herbarium of Harvard University 70: 69-87. http://www.biodiversitylibrary.org/page/39944720\#page/77/mode/1up [accessed 30.07.2013]

Kyndt T, Van Droogenbroeck B, Romeijn-Peeters E, Romero-Motochi JP, Scheldeman X, Goetghebeur P, Van Damme P, Gheysen G (2005) Molecular phylogeny and evolution of Caricaceae based on rDNA internal transcribed spacers and chloroplast sequence data. Molecular Phylogenetics and Evolution 37(2): 442-59. doi: 10.1016/j.ympev.2005.06.017

La Llave P (1832) Descripcion de alguns géneros y especies nuevas de vegetales. Registro Trimestre ó Coleccion de Memorias de Historia, Literatura, Ciencias y Artes1(3): 345358. http://www.biodiversitylibrary.org/page/14631797\#page/373/mode/1 up [accessed 30.07.2013]

Lorence DH, Colín RT (1988) Carica cnidoscoloides (sp. nov.) and sect. Holostigma (sect. nov) of Caricaceae from Southern Mexico. Systematic Botany 13(1): 107-110. doi: $10.2307 / 2419246$

McNeill J, Barrie FR, Buck WR, Demoulin V, Greuter W, Hawksworth DL, Herendeen PS, Knapp S, Marhold K, Prado J, Prud'homme van Reine WF, Smith JF, Wiersema JH, Turland NJ (2012) International Code of Nomenclature for Algae, Fungi, and Plants (Melbourne Code): adopted by the Eighteenth International Botanical Congress Melbourne, Australia, July 2011. Regnum Vegetabile 154. Koeltz Scientific Books. http://www.iapttaxon.org/nomen/main.php [accessed 30.07.2013]

McVaugh R (2001) Caricaceae. In: Anderson WR (Ed) Flora Novo-Galiciana. A descriptive account of the vascular plants of Western Mexico. Vol. 3 Ochnaceae to Losaceae. The University of Michigan Press, Ann Arbor, 461-477.

Ramírez J (1894) La Mocinna heterophylla. Nuevo género de las papayáceas. Anales del Instituto Médico Nacional 1(5): 205-212, pl. II-V. http://archive.org/stream/ analesdelinstitu01 inst\#page/206/mode/2up [accessed 30.07.2013]

Rusby HH (1921) A strange fruit. Torreya 21(3): 47-50. http://www.biodiversitylibrary.org/ item/100133\#page/243/mode/1 up [accessed 30.07.2013]

Standley PC (1924) Caricaceae. In: Standley PC (Ed) Tree and shrubs of Mexico (Passifloraceae-Schrofulariaceae). Contributions from the United States National Herbarium 23(4): 849-853. http://www.biodiversitylibrary.org/page/375754\#page/939/mode/1up [accessed 30.07.2013]

Standley PC (1937) Caricaceae. In: Standley PC (Ed) Studies of American Plants-VII. Publications of the Field Museum of Natural History, Botanical Series 17(2): 200-202. 